\title{
Pengaruh Kepemimpinan Transformasional dan Program Pelatihan dan Pengembangan Terhadap Kinerja Karyawan Melalui Kompetensi Di Petrochina Internasional Jabung Ltd
}

\author{
Gajianto Pangarso Hari Kuncoro, Sihol Situngkir, Syahmardi Yacob \\ Pascasarjana Magister Manajemen Universitas Jambi \\ Correspondence email: rangga_f31@yahoo.com
}

\begin{abstract}
This study aims to examine whether there is an influence of transformational leadership and training and development programs on employee performance with the mediation variable, namely competence. Primary data source using a questionnaire taken on the research object at PetroChina International Jabung Ltd with a total sample of 144 respondents. The study uses quantitative descriptive analysis and data processed with SPSS 24 namely regression analysis and path analysis. The results showed that there was a positive influence on transformational leadership and training and development programs on employee performance. Transformational leadership and training and development programs affect on employee competencies. Employee competence mediates transformational leadership on employee performance and competence also mediates training and development programs on employee performance. The study recommends that the leaders of the PetroChina International Jabung Ltd Office need toreview the policies of improving the implementation of training and development programs and employee competencies so that employees can contribute more productively to the Office.
\end{abstract}

Keywords: Competencies, Employee Performance, Training and Development Programs, Transformational Leadership

\begin{abstract}
Abstrak. Tujuan peneltian ini adalah untuk mengetahui apakah ada pengaruh kepemimpinan transformasional dan program pelatihan dan pengembangan terhadap kinerja karyawan dengan adanya variabel mediasi yaitu kompetensi. Sumber data primer dengan menggunakan kuesioner yang diambil pada objek penelitian di PetroChina International Jabung Ltd dengan jumlah sampel sebanyak 144 responden. Penelitian menggunakan analisis deskriptif kuantitatif dan data diolah dengan SPSS 24 yaitu analisis regresi dan analisis jalur. Hasil penelitian menunjukkan bahwa adanya pengaruh yang positif kepemimpinan transformasional dan program pelatihan dan pengembangan terhadap kinerja karyawan. Kepemimpinan transformasional dan program pelatihan dan pengembangan berpengaruh terhadap kompetensi karyawan. Kompetensi karyawan memediasi kepemimpinan transformasional terhadap kinerja karyawan dan kompetensi juga memediasi program pelatihan dan pengembangan terhadap kinerja karyawan.Penelitian merekomendasikan pimpinan Kantor Petro China International Jabung Ltd meninjau arah kebijakan perbaikan implementasi program pelatihan dan pengembangan serta kompetensi karyawan sehingga karyawan lebih berkontribusi produktif di Kantor.
\end{abstract}

Kata Kunci: Kepemimpinan Transformasional, Kinerja Karyawan, Kompetensi Karyawan, Program Pelatihan dan Pengembangan

\section{Pendahuluan}

Dfinisi tentang kinerja dari para ahli, diketahui bahwa kinerja atau prestasi kerja merupakan hasil kerja yang dicapai seseorang dalam melaksanakan tugas-tugas yang dibebankan kepadanya yang didasarkan atas kecakapan, pengalaman dan kesungguhan dan tepat waktu. Salah satunya oleh Mathis dan Jackson (2012) yang menjelaskan bahwa kinerja pegawai pada dasarnya merupakan apa yang dilakukan atau tidak dilakukan pegawai. Wujud kinerja dapat dilihat dari tingkat prestasi kerja yang berupa hasil kerja, kemampuan dan penerimaan atas kejelasan delegasi tugas serta minat seorang pekerja. Penilaian kinerja di PCJL dilaksanakan sebanyak 2 kali dalam setahun, yaitu penilaian pertengahan tahun (mid year) yang dilaksanakan pada periode Juni-Juli tahun berjalan dan penilaian akhir tahun (year end) yang dilaksanakan pada periode Desember-Januari. Penilaian kinerja dilaksanakan menggunakan 2 komponen utama yaitu Key Perfomance Indicator (KPI) dan Competency (Kompetensi). Komponen KPI merupakan indikator-indikator yang harus dicapai oleh setiap individu, yang merupakan penjabaran atau turunan dari target utama yang harus dicapai oleh perusahaan, seperti target produksi minyak mentah/gas, target penyerapan anggaran dan target penurunan kecelakaan kerja. KPI memiliki bobot sebesar $70 \%$ terhadap total penilaian. Sedangkan kompetensi merupakan indikatorindikator pengembangan diri yang harus dicapai oleh setiap individu karyawan, seperti membangun kemitraan (building partnership), berorientasi pada pencapaian (achievement orientation), dan sebagainya. Kompetensi memiliki bobot sebesar $30 \%$ terhadap total penilaian. Salah satu data sekunder yang diambil dari komponen KPI adalah realisasi penyerapan anggaran yang merupakan salah satu indikator kinerja setiap individu sebagai bagian dari unit kerja untuk merealisasikan rencana kerja dan anggaran yang telah disetujui oleh SKK-Migas 
Data sekunder dari komponen KPI karyawan PCJL adalah jumlah kejadian accident dan incident yang terjadi. Jumlah kejadian ini merupakan idikator kinerja kayawan dalam bidang keselamatan kerja yang menjadi salah satu target utama perusahaan, yaitu untuk mencapay target zero accident atau nihil angka kecelakaan kerja.

Gambar 1.

Angka Frekuensi Kecelakaan Kerja Lapangan Jabung 2017 - 2019

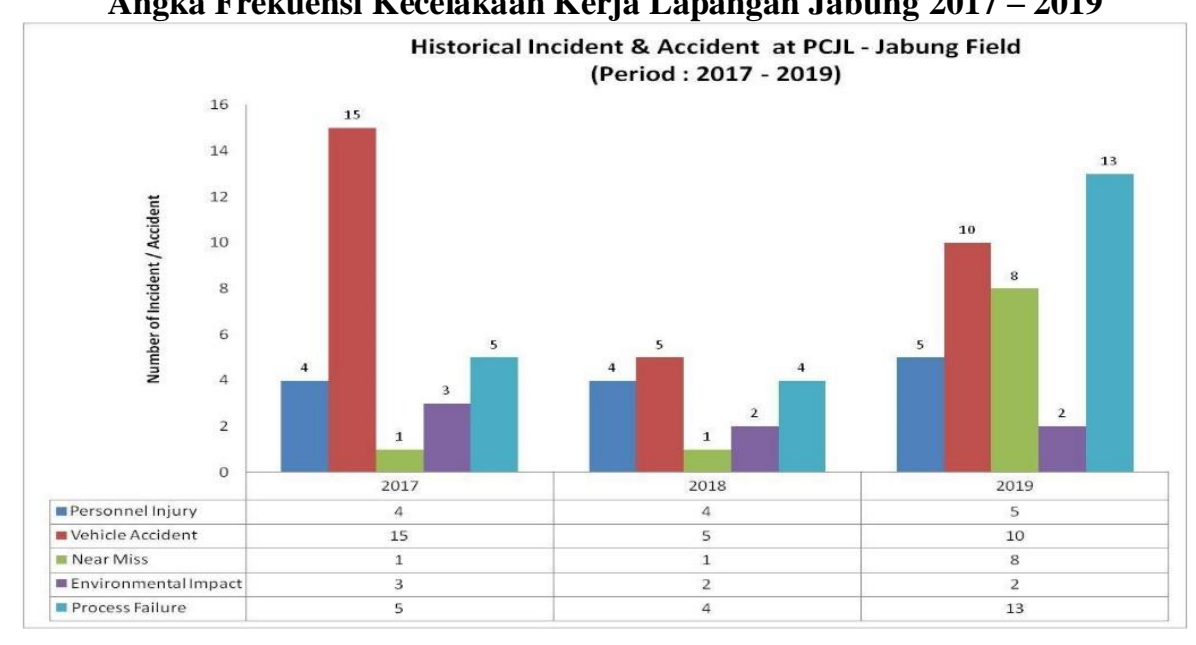

Sumber: data olahan

Berdasarkan paparan diatas, peneliti melihat fenomena bahwa dari hasil penilaian kinerja selama 3 tahun terakhir, diketahui bahwa masih cukup banyak karyawan yang memperoleh nilai akhir kinerja dibawah standar yang ditetapkan oleh perusahaan, yaitu meet minimum requirement (MM) dan unsatisfactory (U). Sisi penyerapan anggaran yang merupakan salah stau indikator kuantitatif terlaksananya program kerja, diketahui juga bahwa realisasi penyerapan selama 3 tahun terakhir masih pada kisaran dibawah 90\%, bahkan untuk tahun 2019 sampai akhir Bulan September penyerapan anggaran masih dibawah 60\%. Indikator lain yang merupakan bagian dari kinerja karyawan Jabung Field PetroChina International Jabung adalah angka incident dan accident yang terjadi dalam operasional Lapangan Jabung masih cukup berfluktuasi dan belum pernah mencapai target yang diharapkan perusahaan yaitu nihil kecelakaan atau zero accident.

Sebagai sebuah organisasi yang memiliki suatu struktur organisasi yang baku, kepemimpinan di PetroChina International Jabung Ltd memegang peranan penting bagi suatu organisasi. Kepemimpinan yang baik dan benar dibutuhkan untuk membuat organisasi dapat meraih tujuan yang diharapkan, termasuk juga dalam hal kinerja karyawan. Jajaran pimpinan diharapkan dapat memelihara kesinambungan dan kelangsungan proses perubahan yang membawa dampak positif bagi karyawan. Tipe atau gaya kepemimpinan yang diterapkan oleh pemimpin, dalam hal ini jajaran manajemen akan dapat terlihat dari berbagai program-program yang ditujukan pada peningkatan kinerja karyawan. Gang Wang, In-Sue Oh, Stephen H. Courthright dan Amy E. Coulbert (2011) melalui penelitian mereka menunjukkan bahwa kepemimpinan transformasional berhubungan positif dengan kinerja, baik pada level individu, tim maupun organisasi. Di PetroChina International Jabung Ltd, peranan pimpinan dalam hal ini jajaran manajemen baik yang berada di lapangan maupun di kantor pusat dalam melakukan perubahan dalam berbagai bidang sangat dominan. Banyak program yang di-inisiasi oleh jajaran pimpinan yang ditujukan untuk meningkatkan kompetensi karyawan. Adanya program-program tersebut diharapkan dapat memberikan dampak langsung berupa peningkatan kompetensi yang dimiliki oleh karyawan dan pada akhirnya berdampak juga pada kinerja karyawan.

Program pelatihan dan pengembangan di PetroChina International Jabung Ltd, merupakan salah satu program yang ditujukan untuk pengelolaan sumber daya manusia khususnya untuk meningkatkan pengetahuan dan keterampilan bagi para karyawan. Seperti dijelaskan Partlow (1996), Tihanyi et al. (2000) dan Boudreau et al. (2001) bahwa karyawan yang terlatih memiliki kinerja yang baik dibandingkan dengan karyawan yang tidak terlatih. Program pelatihan dan pengembangan di PCJL disusun dan dilaksanakan berdasarkan analisa kebutuhan pelatihan yang disebut Training Need Analysis (TNA) yang dibuat setiap tahun melalui kerjasama antara pimpinan unit dengan Departemen Human Resources Development (HRD). TNA dibuat setahun sekali oleh setiap Kepala departemen ke HRD untuk kemudian dianalisa dan mendapatkan persetujuan lebih lanjut. Adanya program pelatihan ini diharapkan dapat meningkatkan kompetensi yang dimiliki oleh setiap karyawan, khususnya dalam mengisi gap antara pengetahuan dan keterampilan yang sudah dimiliki karyawan dengan kompetensi yang dibutuhkan oleh perusahaan dalam mencapai target yang telah ditetapkan. Penelitian terdahulu mengenai kepemimpinan transformasional, pelatihan dan pengembangan, kompetensi dan kinerja seperti yang dilakukan Shelley D. Dionne, dkk (2003), Juliana Thompson (2012), Nadine J. Kaslow \& Carol A.Falender (2012), Raja Abdul Ghafoor Khan, dkk (2011), Fendy Levy 
Kambey\&Suharnomo (2015) menunjukkan bahwa masih sedikitnya penelitian yang mengkaji hubungan diantara ketiga variabel ini, terutama peran kompetensi sebagai mediator dalam hubungan antara kepemimpinan transformasional serta pelatihan dan pengembangan dengan kinerja. Fakta inilah yang kemudian menjadikan dasar bagi peneliti untuk lebih lanjut melakukan kajian empiris lebih lanjut untuk mengetahui sejauh mana pengaruh kepemimpinan transformasional serta Pelatihan dan Pengembangan yang dimediasi oleh variabel kompetensi terhadap kinerja pada karyawan unit Lapangan Jabung di PetroChina International Jabung Ltd. Hasil yang diperoleh melalui penelitian yang akan dilakukan ini diharapkan dapat menjadi masukan sekaligus bahan pertimbangan bagi jajaran pimpinan dan manajemen PetroChina International Jabung Ltd terkait tentang penerapan konsep kepemimpinan khususnya kepemimpinan transformasional serta program pelatihan dan pengembangan bagi peningkatan kompetensi karyawan yang berujung pada peningkatan kinerja.

Uraian di atas, maka yang menjadi masalah penelitian (research problem) adalah bagaimana pengaruh kepemimpinan transformasional dan pelatihan \& pengembangan terhadap kinerja karyawan melalui kompetensi sebagai variabel mediator di PetroChina International Jabung Ltd., dengan pertanyaaan penelitian (research question) utama yaitu: 1) apakah terdapat pengaruh antara kepemimpinan transformasional (transformation leadership) terhadap kompetensi karyawan Petrochina International Jabung ltd; 2) apakah terdapat pengaruh antara pelatihan dan pengembangan (training and development) terhadap kompetensi karyawan PetroChina International Jabung Ltd; 3) apakah terdapat pengaruh antara kepemimpinan transformasional (transformation leadership) terhadap kinerja karyawan PetroChina International Jabung Ltd; 4) apakah terdapat pengaruh antara program pelatihan dan pengembangan (training and development) terhadap kinerja karyawan PetroChina International Jabung Ltd; 5) apakah terdapat pengaruh antara kompetensi terhadap kinerja karyawan PetroChina International Jabung Ltd; 6) Apakah kompetensi dapat memediasi pengaruh antara kepemimpinan transformasional (Transformation Leadership) terhadap kinerja karyawan PetroChina International Jabung Ltd; 7) apakah kompetensi dapat memediasi pengaruh antara pelatihan dan pengembangan (training and development) terhadap kinerja karyawan PetroChina International Jabung Ltd.

Tujuan penelitian ini adalah: 1) untuk menguji pengaruh kepemimpinan transformasional terhadap kompetensi karyawan PetroChina International Jabung Ltd; 2) untuk menguji pengaruh pelatihan dan pengembangan terhadap kompetensi karyawan PetroChina International Jabung Ltd; 3) untuk menguji pengaruh kepemimpinan transformasional terhadap Kinerja karyawan PetroChina International Jabung Ltd; 4) untuk menguji pengaruh pelatihan dan pengembangan terhadap kinerja karyawan PetroChina International Jabung Ltd; 5) untuk menguji pengaruh kompetensi terhadap kinerja karyawan PetroChina International Jabung Ltd; 5) untuk menguji efek mediasi Kompetensi dalam pengaruh antara kepemimpinan transformasional terhadap kinerja karyawan PetroChina International Jabung Ltd; 6) untuk menguji efek mediasi kompetensi dalam pengaruh antara pelatihan dan pengembangan terhadap kinerja karyawan PetroChina International Jabung Ltd.

\section{Metode}

Populasi dalam penelitian ini adalah karyawan golongan staff (Grade 8 - 15) di lapangan Jabung PetroChina International Jabung Ltd yang secara struktural departemen berada dibawah Field Manager, dimana total berjumlah 225 orang. Pengambilan sampel dalam penelitian ini akan menggunakan teknik stratified random sampling. Hal ini dikarenakan setiap anggota populasi tersebar di beberapa departemen atau unit dalam organisasi, dimana anggota dari masing-masing departemen memiliki peluang yang sama untuk tepilih sebagai sampel penelitian. Untuk menentukan jumlah ukuran sampel yang akan digunakan dalam penelitian ini dilakukan dengan menggunakan atbel Krecjie \& Morgan. Pada penelitian ini jumlah sampel yang digunakan sebesar 225 orang dan dari Tabel Krecjie \& Morgan, diperoleh sampel sebanyak 144 orang karyawan, setelah itu ditentukan melalui alokasi sampel proporsional (Usman dan Purnomo, 2006).

Data Transformational Leadership, Pelatihan dan Pengembangan, Kompetensi dan Kinerja dalam penelitian ini akan dikumpulkan dengan menggunakan kuesioner. Jenis kuesioner yang akan digunakan adalah kuesioner tertutup dengan format skala ordinal yang memiliki lima alternatif respon, yaitu sangat tidak setuju (STS), tidak setuju (TS), kurang setuju (KS), setuju (S), dan sangat setuju (SS). Hasil isian kuesioner yang telah diperoleh dari 144 orang responden tersebut kemudian akan ditabulasikan dan dianalisis. Analisis data yang digunakan untuk penelitian ini adalah analisis data yang bersifat kuantitatif yaitu berguna untuk mengukur secara kuantitatif mengenai pengaruh variabel independen secara langsung terhadap variabel dependen melalui variabel mediasi. Metode analisis yang digunakan dalam penelitian ini menggunakan metode analisis jalur (Path Analysis). Software yang digunakan dalam penelitian ini adalah mengunakan program SPSS Versi 24 for windows. Analisis statistik data penelitian ini menggunakan analisis jalur (Path Analysis) untuk melihat pengaruh langsung dan tidak langsung antar variabel. Peneliti menggunakan analisis jalur pada penelitian ini karena analisis jalur memungkinkan peneliti dapat menguji proposisi teoritis mengenai hubungan sebab akibat. Analisis yang dilakukan dengan menggunakan korelasi dan regresi sehingga dapat diketahui untuk sampai pada variabel dependen terakhir, harus lewat jalur langsung atau melalui 
intervening. Modelnya digambarkan dalam bentuk lingkaran dan panah, dimana anak panah tunggal menunjukkan sebagai penyebab dikarenakan pada masing-masing variabel dalam suatu model sebagai variabel tergantung (pemberi respon) sedang yang lain sebagai penyebab. Uji dalam penelitian ini terdiri dari: 1) Uji Normalitas; 2) Uji Homogenitas; 3) Uji Linearitas; 4) Uji Multikolinieritas.

\section{Hasil}

Pengaruh Kepemimpinan Transformasional terhadap Kinerja Karyawan.. Berdasarkan hasil perhitungan, diperoleh signifikansi $0,004<\alpha=0,05$, sehingga Ho ditolak dan Ha diterima. Artinya ada pengaruh antara Kepemimpinan Transformasional terhadap Kinerja dan dianggap signifikan dengan angka signifikansi 0,004 $<\alpha=$ 0,05. Pengaruh Pelatihan \& Pengembangan terhadap Kinerja Karyawan, berdasarkan hasil perhitungan, diperoleh signifikansi $0,006<\alpha=0,05$, sehingga Ho ditolak dan Ha diterima. Artinya ada pengaruh antara Pelatihan \& Pengembangan terhadap Kinerja dan dianggap signifikan dengan angka signifikansi $0,006<\alpha=0,05$. Pengaruh Kompetensi terhadap Kinerja Karyawan, berdasarkan hasil perhitungan, diperoleh signifikansi $0,018<\alpha=0,05$, sehingga Ho ditolak dan Ha diterima. Artinya ada pengaruh antara Kompetensi terhadap Kinerja karyawan dan dianggap signifikan dengan angka signifikansi $0,018<\alpha=0,05$.

Hasil uji regresi di atas merupakan hasil pengolahan yang menunjukkan ada tidaknya pengaruh variabel Kepemimpinan Transformasional (X1), Pelatihan \& pengembangan (X2), dan kompetensi karyawan (Z) terhadap variabel kinerja karyawan $(\mathrm{Y})$. Persamaan regresi yang diperoleh dari hasil uji di atas adalah:

$\mathrm{Y}=2,996+0,249 \mathrm{X} 1+0,174 \mathrm{X} 2+0,242 \mathrm{Z}+\mathrm{e}$

\section{Pengujian Variabel Mediasi}

Strategi Causal Step (Pengaruh Kepemimpinan Transformasional terhadap Kinerja Karyawan dengan Dimediasi Kompetensi)

Hasil analisis ditemukan bahwa Kepemimpinan Transformasional signifikan terhadap Kinerja Karyawan, setelah dapat mengontrol Kompetensi karena nilai signifikansi $0,0174<\alpha=0,05$ dan koefisien regresi (b) $=0,2421$. Selanjutnya ditemukan dirrect effect c' sebesar 0,2953 yang lebih besar dari $\mathrm{c}=0$, Pengaruh variabel independen Kepemimpinan Transformasional terhadap variabel dependen Kinerja Karyawan berkurang dan signifikan 0,0174< $\alpha$ $=0,05$ setelah mengontrol variabel mediasi Kompetensi. Dapat disimpulkan bahwa model ini termasuk ke dalam partial mediation atau terjadi mediasi, dimana variabel Kepemimpinan Transformasional mampu mempengaruhi secara langsung variabel Kinerja Karyawan dan secara tidak langsung dapat melibatkan variabel mediasi Kompetensi atau dapat dikatakan bahwa Kompetensi memediasi hubungan antara Kepemimpinan Transformasional dan Kinerja Karyawan.

\section{Strategi Causal Step (Pengaruh Pelatihan \& Pengembangan terhadap Kinerja Karyawan dengan Dimediasi Kompetensi)}

Hasil analisis ditemukan bahwa Pelatihan \& Pengembangan signifikan terhadap Kinerja Karyawan, setelah mengontrol kompetensi dengan nilai signifikansi $0,0107<\alpha=0,05$ dan koefisien regresi $(b)=0,2543$. Selanjutnya ditemukan dirrect effect c' sebesar 0,2754 yang lebih besar dari c $=0,2543$. Pengaruh variabel independen Pelatihan $\&$ Pengembangan terhadap variabel dependen Kinerja Karyawan berkurang dan signifikan $0,009<\alpha=0,05$ setelah mengontrol variabel mediasi Kompetensi. Dapat disimpulkan bahwa model ini termasuk ke dalam partial mediation atau terjadi mediasi, dimana variabel Pelatihan \& Pengembangan mampu mempengaruhi secara langsung variabel Kinerja Karyawan dan secara tidak langsung dapat melibatkan variabel mediasi Kompetensi atau dapat dikatakan bahwa Kompetensi memediasi hubungan antara Pelatihan \& Pengembangan dan Kinerja karyawan. Perhitunganperhitungan tersebut digunakan untuk membuat Diagram Jalur Model 2 sebagai berikut :

Gambar 2

Diagram Jalur Model 2

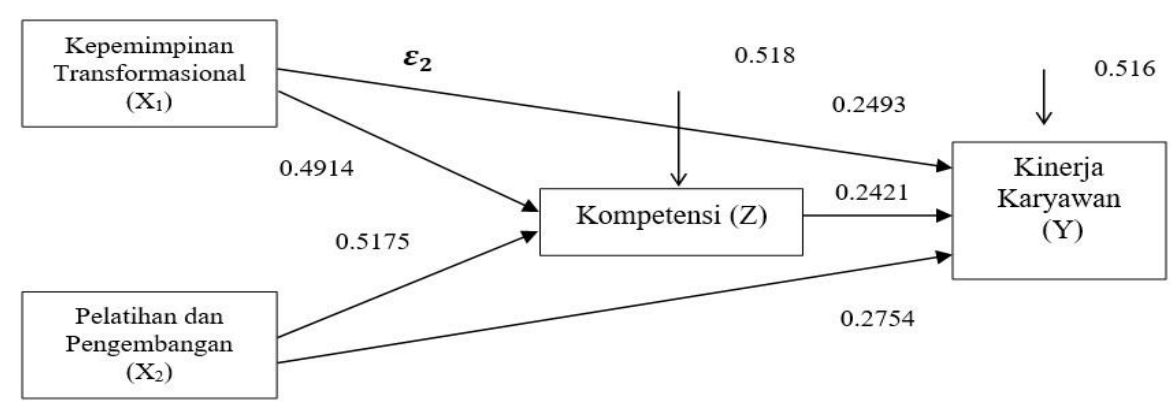


Berdasarkan Gambar 2 dapat disimpulkan persamaan strukturalnya sebagai berikut :

Substruktur $1: Z=0,4914 X 1+0,4161 X 2+0,518$

Berdasarkan persamaan di atas dapat diartikan apabila Kepemimpinan Transformasional naik 1 satuan, maka Kompetensi akan mengalami kenaikan sebesar 0,4914 dengan asumsi variabel Pelatihan \& Pengembangan konstan. Selanjutnya, apabila Pelatihan \& Pengembangan naik 1 satuan, maka Kompetensi akan mengalami kenaikan sebesar 0,4161 dengan asumsi variabel Kepemimpinan Transformasional konstan. Kedua variabel independen (Kepemimpinan transformasional dan Pelatihan \& pengembangan) dapat menjelaskan variabel kompetensi karyawan sebesar 51,8\%, sedangkan sisanya sebesar 0,482 atau 48,2\% dijelaskan oleh variabel bebas lainnya.

Substruktur $2: \mathrm{Y}=0,2493 \mathrm{X} 1+0,1740 \mathrm{X} 2+0,2421 \mathrm{Z}+0,516$

Berdasarkan persamaan di atas dapat diartikan apabila Kepemimpinan Transformasional naik 1 satuan, maka Kinerja karyawan akan mengalami kenaikan sebesar 0,2493 dengan asumsi variabel Pelatihan \& Pengembangan dan Kompetensi karyawan konstan. Selanjutnya, apabila Pelatihan \& Pengembangan naik 1 satuan, maka Kinerja karyawan akan mengalami kenaikan sebesar 0,1740 dengan asumsi variabel Kepemimpinan Transformasional dan Kompetensi karyawan. Apabila Kompetensi karyawan naik 1 satuan, maka kinerja Karyawan akan mengalami kenaikan sebesar 0,2421 dengan asumsi variabel Pelatihan \& Pengembangan dan Kepemimpinan Transformasional konstan. Ketiga variabel independen (Kepemimpinan Transformasional, Pelatihan \& Pengembangan dan Kompetensi karyawan) dapat menjelaskan variabel Kinerja karyawan sebesar 51,6\%, sedangkan sisanya sebesar 0,484 atau 48,4\% dijelaskan oleh variabel bebas lainnya.

\section{Pengaruh Kepemimpinan Transformasional Terhadap Kompetensi Karyawan}

Hasil pengujian dalam penelitian ini menunjukkan bahwa Kepemimpinan Transformasional memiliki pengaruh secara positif dan signifikan terhadap Kompetensi karyawan. Hasil ini menunjukkan bahwa semakin baik Kepemimpinan Transformasional yang ditunjukkan oleh pemimpin maka akan semakin tinggi pula Kompetensi karyawan. Arah pengaruh yang positif dapat diinterpretasikan bahwa semakin baik Kepemimpinan Transformasional yang ditunjukkan dan diberikan oleh jajaran pimpinan terhadap karyawan maka akan meningkatkan Kompetensi dari karyawan yang dipimpinnya.

Hasil rekapitulasi kuesioner pada variabel Kepemimpinan Transformasional menunjukkan bahwa rata-rata nilai yang cukup tinggi untuk masing-masing nilai dimensi kepemimpinan transformasional. Hasil tersebut menggambarkan bahwa jajaran pimpinan di PetroChina International Jabung Ltd_mampu menunjukkan standar tinggi dari tingkah laku moral dan etika, serta menggunakan kemampuannya untuk menekankan pentingnya nilai-nilai, asumsi-asumsi, komitmen dan keyakinan, serta memiliki tekad untuk mencapai tujuan dengan senantiasa mempertimbangkan akibat-akibat moral dan etik dari setiap keputusan yang dibuat. Secara keseluruhan, rata-rata nilai untuk variabel Kepemimpinan Transformasional juga termasuk dalam kategori tinggi sehingga Kepemimpinan Transformasional berpengaruh positif terhadap kompetensi karyawan. Hasil ini sejalan dengan penelitian yang dilakukan oleh Francisco et al. (2005), yang dalam hasil penelitiannya menyatakan perubahan orientasi pemimpin, yakni; melakukan transformasi nilai-nilai, menyebabkan adanya peningkatan kinerja karyawan.

Berdasarkan analisis deskriptif dapat dicatat bahwa Kepemimpinan Transformasional telah dijalankan dengan baik di PetroChina International Jabung Ltd. Terbukti dengan diimplementasikan kepemimpinan tranformasioanal dengan rata-rata skor 4,44 dengan katogori sangat baik. Ini artinya bahwa secara rata-rata dimensi- dimensi yang ada dalam Kepemimpinan Transformasional telah dapat berjalan dengan baik. Terdapat satu dimensi yaitu Stimulasi Intelektual (Intelectual Stimulation) tergolong dengan skor terendah karena masih rendah nya "Atasan saya mampu menyelesaikan masalah dari berbagai sudut pandang". Tentu saja dengan adanya kebijakan perbaikan dengan masalah ini berpotensi semakin dapat meningkatkan kepemimpinan di PetroChina International Jabung Ltd.

\section{Pengaruh Pelatihan \& Pengembangan Terhadap Kompetensi Karyawan}

Hasil pengujian dalam penelitian ini menunjukkan bahwa Pelatihan \& Pengembangan memiliki pengaruh secara positif dan signifikan terhadap kompetensi karyawan. Hasil ini menunjukkan bahwa semakin baik pelatihan maka akan semakin tinggi pula kompetensi karyawan. Arah pengaruh yang positif dapat diinterpretasikan bahwa semakin baik pelatihan dan pengembangan yang diberikan terhadap karyawan maka akan meningkatkan kompetensi yang dimiliki karyawan dalam menjalankan tugas dan pekerjaan. Hasil ini sejalan dengan penelitian yang dilakukan oleh Bergevoet dan Van Woerkum (2006) serta Bryant dan Poustie (2001) yang menyimpulkan bahwa kompetensi dinamis tunduk pada proses pembelajaran dan pengembangan dan dapat ditingkatkan dengan pelatihan dan praktik. Demikian pula, kompetensi ditingkatkan dengan latihan, dan dapat menurun dari waktu ke waktu tanpa latihan yang memadai 
Hasil rekapitulasi kuesioner pada variabel Pelatihan dan Pengembangan menunjukkan bahwa skor tertinggi adalah dimensi pelatihan pada pernyataan "Materi pelatihan yang diberikan sesuai dengan pekerjaan saya" dan "Pengetahuan dan keterampilan yang diperoleh melalui pelatihan dapat diterapkan pada lingkungan dimana saya bekerja" dan skor terendah adalah dimensi pengembangan pada pernyataan "Karyawan senior dan atasan berperan sebagai mentor (pembimbing) saya dalam melaksanakan pekerjaan". Hasil tersebut menggambarkan bahwa PetroChina International Jabung Ltd telah memberikan pelatihan lebih terarah pada peningkatan kemampuan dan keahlian SDM organisasi yang berkaitan dengan jabtan atau fungsi yang menjadi tanggung jawab individu yang bersangkutan saat ini (current job oriented) dan sesuai dengan Sasaran yang ingin dicapai dan suatu program pelatihan yaitu peningkatan kinerja individu dalam abatan atau fungsi saat ini. Secara keseluruhan, rata-rata nilai untuk variabel pelatihan dan pengembangan termasuk dalam kategori baik, sehingga dapat disimpulkan bahwa karyawan dapat merasakan iklim organisasi yang baik, sehingga pelatihan dan pengembangan berpengaruh positif dan signifikan terhadap kompetensi karyawan.

Berdasarkan analisis deskriptif dapat dicatat bahwa Pelatihan dan Pengembangan di PetroChina International Jabung Ltd tergolong baik. Terbukti dari hasil analisis deskriptif yang menunjukkan bahwa pelatihan dan pengembangan dengan rata-rata 4,20 dengan kategori baik. Ini artinya bahwa secara rata-rata dimensi pada varibel pelatihan dan pengembangan tergolong baik Terdapat satu dimensi pengembangan pada pernyataan "Karyawan senior dan atasan berperan sebagai mentor (pembimbing) saya dalam melaksanakan pekerjaan" memiliki skor terendah. Tentu saja dengan adanya sosialisasi tentang hal ini ke depan akan dapat meningkatkan kompetensi di PetroChina International Jabung Ltd.

\section{Pengaruh Kepemimpinan Transformasional Terhadap Kinerja Karyawan}

Hasil pengujian dalam penelitian ini menunjukkan bahwa Kepemimpinan Transformasional memiliki pengaruh secara positif dan signifikan terhadap kinerja karyawan. Hasil ini menunjukkan bahwa semakin kuat pemahaman dan pelaksanaankepemimpinan transformasional maka semakin baik kinerja karyawan. Arah pengaruh yang positif yang diperoleh dapat diinterpretasikan bahwa semakin baik Kepemimpinan Transformasional yang ditunjukkan dan diberikan oleh atasan terhadap karyawan, maka akan mampu meningkatkan kinerja karyawan menjadi lebih baik lagi. Pimpinan PetroChina International Jabung Ltd telah menyampaikan pesan, maksud dan bentuk dukungan motivasi terhadap karyawan sehingga karyawan dapat merasakan dampak yang positif. Hasil ini juga memperkuat penelitian serupa yang dilakukan oleh Gang Wang, In-Sue Oh, Stephen H. Courthright dan Amy E. Coulbert (2011) yang melalui penelitian mereka menunjukkan bahwa kepemimpinan transformasional berhubungan positif dengan kinerja di seluruh jenis kriteria dan tingkat analisis. Berdasarkan analisis deskriptif dapat dicatat bahwa kepemimpinan transformasional telah dijalankan dengan baik di PetroChina International Jabung Ltd. Terbukti dengan diimplementasikan kepemimpinan tranformasioanal dengan rata-rata skor 4,44. Ini artinya bahwa secara ratarata dimensi kepemimpinan transformasional telah berjalan dengan baik namun dimensi stimulasi intelektual tergolong dengan skor terendah karena "Atasan saya mampu menyelesaikan masalah dari berbagai sudut pandang". Diharapkan dengan adanya kebijakan perbaikan dengan masalah ini berpotensi semakin dapat mendongkrak kinerja karyawan PetroChina International Jabung Ltd.

\section{Pengaruh Pelatihan dan Pengembangan Terhadap Kinerja Karyawan}

Hasil pengujian dalam penelitian ini menunjukkan bahwa pelatihan dan pengembangan memiliki pengaruh secara positif dan signifikan terhadap kinerja karyawan. Hasil ini menunjukkan bahwa semakin baik pelatihan dan pengembangan maka akan semakin baik pula kinerja karyawan. Arah pengaruh yang positif dapat diinterpretasikan bahwa semakin baik pelatihan dan pengembangan yang ditunjukkan dan diberikan oleh organisasi terhadap karyawan. Maka akan mampu meningkatkan kinerja karyawan menjadi lebih baik lagi. Hasil penelitian ini sejalan dengan hasil penelitian yang dilakukan oleh Partlow (1996), Tihanyi et al. (2000) dan Boudreau et al. (2001) yang menjelaskan bahwa karyawan yang terlatih memiliki kinerja yang baik dibandingkan dengan karyawan yang tidak terlatih. Hasil rekapitulasi kuesioner pada variabel pelatihan dan pengembangan menunjukkan bahwa skor tertinggi adalah dimensi pelatihan pada pernyataan "Materi pelatihan yang diberikan sesuai dengan pekerjaan saya" dan "Pengetahuan dan keterampilan yang diperoleh melalui pelatihan dapat diterapkan pada lingkungan dimana saya bekerja" dan skor terendah adalah dimensi pengembangan pada pernyataan "Karyawan senior dan atasan berperan sebagai mentor (pembimbing) saya dalam melaksanakan pekerjaan". Hasil tersebut menggambarkan bahwa PetroChina International Jabung Ltd telah memberikan pelatihan lebih terarah pada peningkatan kemampuan dan keahlian SDM organisasi yang berkaitan dengan jabatan atau fungsi yang menjadi tanggung jawab individu yang bersangkutan saat ini (current job oriented) dan sesuai dengan Sasaran yang ingin dicapai dan suatu program pelatihan yaitu peningkatan kinerja individu dalam jabatan atau fungsi saat ini.Secara keseluruhan, rata-rata nilai untuk variabel pelatihan dan pengembangan termasuk dalam kategori baik, sehingga dapat disimpulkan bahwa karyawan dapat merasakan manfaat pelatihan dan pengembangan yang telah diberikan oleh Jabung PetroChina 
International Jabung Ltd. Terbukti dari hasil analisis deskriptif yang menunjukkan bahwa dimensi pelatihan dan pengembangan memiliki rata-rata skor 4,20. Ini artinya bahwa secara rata-rata dimensi pelatihan dan pengembangan tergolong baik namun dimensi pengembangan memiliki skor terendah karena "Karyawan senior dan atasan berperan sebagai mentor (pembimbing) saya dalam melaksanakan pekerjaan". Diharapkan dengan adanya sosialisasi tentang hal ini tentu akan menguatkan implementasi pelatihan dan pengembangan di PetroChina International Jabung Ltd dengan kebih baik lagi.

\section{Pengaruh Kompetensi Karyawan Terhadap Kinerja Karyawan}

Hasil pengujian dalam penelitian ini menunjukkan bahwa kompetensi karyawan memiliki pengaruh secara positif dan signifikan terhadap kinerja karyawan. Hasil ini menunjukkan bahwa semakin tinggi kompetensi karyawan pada organisasi maka akan mampu meningkatkan kinerja karyawan. Arah pengaruh yang positif dapat diinterpretasikan bahwa semakin tinggi kompetensi yang ditunjukkan karyawan maka akan menciptakan peningkatan kinerja yang lebih baik. Seperti halnya dijelaskan oleh Armstrong dan Baron (1998) bahwa kompetensi merupakan dimensi perilaku yang berada dibelakang kinerja kompeten.

Hasil rekapitulasi kuesioner pada variabel kompetensi karyawan dapat diketahui bahwa skor tertinggi terdapat pada dimensi Keterampilan dan pada variabel kinerja karyawan adalah Kreativitas. Dari pernyataan tersebut dapat ditarik kesimpulan bahwa karyawan pada PetroChina International Jabung Ltd memiliki kemampuan untuk melaksanakan suatu tugas tertentu dengan baik secara fisik maupun mental. Kemampuan karyawan untuk bekerja di dalam tim sehingga tugas atau pekerjaan dapat terselesaikan secara efektif dan efesien sebagai kosekuensi dalam bekerja sehingga kinerja karyawan menjadi lebih baik. Dengan demikian mampu untuk mencapai kinerja tertinggi. Hal tersebut telah menjelaskan mengenai hubungan antara kompetensi dengan kinerja karyawan. Oleh sebab itu, variabel kompetensi karyawan dan kinerja karyawan berada dalam kategori baik sehingga kompetensi karyawan berpengaruh positif dan signifikan terhadap kinerja karyawan.

Berdasarkan analisis deskriptif dapat dicatat bahwa implementasi kompetensi di PetroChina International Jabung Ltd tergolong baik. Terbukti dari hasil analisis deskriptif yang menunjukkan bahwa dimensi motif memiliki rata-rata skor 4,28; Sifat 4,32; Konsep Diri 4,25; Pengetahuan 4,33; Keterampilan 4,36. Ini artinya bahwa secara ratarata dimensi kompetensi telah diimplementasikan dengan baik. Namun pada dimensi konsep diri terutama indikator 'Saya selalu yakin bahwa dengan kemampuan saat ini, Saya dapat menyelesaikan tugas dengan baik' memiliki skor terendah. Diharapkan dengan adanya sosialisasi serta program-program pelatihan dan pengembangan yang tepat diharapkan dapat terjadinya perbaikan hal ini yang pada akhirnya akan menguatkan implementasi kompetensi di PetroChina International Jabung Ltd dan berpotensi berdampak pada peningkatan kinerja karyawan.

\section{Pengaruh Kepemimpinan Transformasional Terhadap Kinerja Karyawan Melalui Kompetensi Karyawan}

Hasil pengujian dalam penelitian ini menunjukkan bahwa Kepemimpinan Transformasional berpengaruh positif dan signifikan terhadap kinerja karyawan dengan dimediasi oleh kompetensi. Hasil ini menunjukkan bahwa semakin baik kepemimpinan transformasional maka akan mampu menciptakan kompetensipada diri karyawan. Sehingga, pada akhirnya akan berpengaruh terhadap peningkatan kinerja karyawan. Arah pengaruh yang positif dapat diinterpretasikan bahwa semakin baik kepemimpinan transformasional yang diberikan dan ditunjukkan oleh atasan maka akan semakin tinggi pula kompetensi yang ditunjukkan oleh karyawan dengan demikian karyawan mampu untuk meningkatkan kinerjanya.

Hasil ini sejalan dengan temuan penelitian yang dilakukan oleh Hasil rekapitulasi kuesioner pada variabel kepemimpinan transformasional menunjukkan bahwa rata-rata nilai yang tinggi untuk dimensi pengaruh individu. Untuk variabel kompetensi dapat diketahui bahwa skor tertinggi terdapat pada dimensi keterampilan dan pada variabel kinerja karyawan adalah pada dimensi kreativitas. Dari pernyataan tersebut dapat ditarik kesimpulan bahwa dengan adanya dorongan dan motivasi yang diberikan atasan untuk karyawan untuk berkembangan lebih maju sehingga terbentuk kompetensi pada karyawan. Hal ini membuat karyawan untuk semangat terus bekerja keras sebagai kosekuensi dalam bekerja untuk meningkatkan kualitas kerja. Dengan kualitas kerja yang baik maka akan mampu untuk mencapai kinerja yang lebih tinggi, sehingga kepemimpinan transformasional berpengaruh positif dan signifikan terhadap kinerja karyawan melalui kompetensi karyawan sebagai variable mediator.

Sebagaimana dibahas sebelumnya bahwa berdasarkan analisis deskriptif dapat dicatat bahwa kepemimpinan transformasional telah dijalankan dengan baik pada PetroChina International Jabung Ltd. Terbukti dengan diimplementasikan kepemimpinan tranformasional dengan rata-rata skor 4,44. Ini artinya bahwa secara rata-rata dimensi kepemimpinan telah berjalan dengan baik, dengan salah satu dimensi yaitu stimulasi intelektual dengan skor terendah. Diharapkan dengan adanya kebijakan perbaikan dengan masalah ini tentu saja berpotensi semakin dapat mendongkrak kinerja karyawan PetroChina International Jabung Ltd baik langsung maupun melalui kompetensi karyawan. 


\section{Simpulan}

Berdasarkan hasil penelitian pengaruh Kepemimpinan Transformasional dan Pelatihan \& Pengembangan terhadap Kinerja karyawan melalui kompetensi pada 144 orang responden yang dilakukan padaPetroChina International Jabung Ltd, maka penulis menarik kesimpulan sebagai berikut:

1. Kepemimpinan Transformasional berpengaruh positif dan signifikan terhadap kompetensi karyawan pada PetroChina International Jabung Ltd. Ini artinya bahwa implementasi kepemimpinan transformasional telah berkontribusi dalam menciptakan kompetensi pada karyawan. Hal ini ditunjukkan oleh kontribusi yang baik dari semua dimensi kepemimpinan transformasional

2. Pelatihan \& Pengembangan berpengaruh positif dan signifikan terhadap Kompetensi karyawan pada PetroChina International Jabung Ltd. Ini artinya bahwa pelatihan dan pengembangan telah berperan dalam upaya peningkatan kompetensi karyawan dan hal ini ditunjukkan oleh kontribusi yang baik dari masing-masing dimensi pelatihan dan pengembangan.

3. Kepemimpinan Transformasional berpengaruh positif dan signifikan terhadap Kinerja karyawan pada PetroChina International Jabung Ltd. Semakin baik kepemimpinan transformasional yang ditunjukkan dan diberikan oleh atasan terhadap karyawan, maka akan mampu meningkatkan kinerja karyawan menjadi lebih baik lagi. Hal ini juga didukung kontribusi yang baik dari masing-masing dimensi kepemimpinan transformasional.

4. Pelatihan dan Pengembangan berpengaruh positif dan signifikan terhadap kinerja karyawan pada PetroChina International Jabung Ltd.Ini artinya bahwa pelatihan dan pengembangan telah berperan dalam meningkatkan kinerja karyawan kearah yang lebih baik, dan hal ini ditunjukkan oleh kontribusi yang baik dari masing-masing dimensi pelatihan dan pengembangan.

5. Kompetensi karyawan berpengaruh positif dan signifikan terhadap kinerja karyawan pada PetroChina International Jabung Ltd. Semakin tinggi kompetensi karyawan yang ditunjukkan karyawan maka akan menciptakan peningkatan kinerja yang lebih baik. Hal ini juga didukung secara positif atas kontribusi yang baik dari semua dimensi kompetensi karyawan.

6. Kepemimpinan transformasional berpengaruh positif dan signifikan terhadap kinerja karyawan melalui kompetensi karyawan pada PetroChina International Jabung Ltd. Kompetensi karyawan merupakan variabel mediator antara kepemimpinan transformasional dan kinerja karyawan. Semakin baik kepemimpinan transformasional yang diberikan dan ditunjukkan oleh atasan maka akan semakin tinggi pula kompetensi karyawan yang ditunjukkan oleh karyawan dengan demikian karyawan mampu untuk meningkatkan kinerjanya. Hal ini juga didukung kontribusi yang baik dari masing-masing dimensi kepemimpinan transformasional.

7. Pelatihan dan pengembangan berpengaruh positif dan signifikan terhadap kinerja karyawan melalui kompetensi karyawan pada PetroChina International Jabung Ltd. Kompetensi karyawan merupakan variabel mediator antara pelatihan dan pengembangan dan kinerja karyawan. Semakin baik pelatihan dan pengembangan yang diberikan organisasi maka akan mampu meningkatkan kompetensiyang tinggi pula pada diri karyawan sehingga pada akhirnya mampu mempengaruhi peningkatan kinerja karyawan. Hal ini didukung oleh kontribusi yang baik dari masing-masing dimensi pelatihan dan pengembangan.

\section{Daftar Pustaka}

Alwi, Syafaruddin. (2001). Manajemen Sumber Daya Manusia, Strategi Keunggulan Kompetitif. BPFE UGM, Yogyakarta.

Andy Pradana, Martha. (2013). Pengaruh Gaya Kepemimpinan Transformasional dan Transaksional terhadap Kinerja Karyawan: studi kasus pada karyawan tetap PT. Mustika Bahana Jaya. Lumajang: Universitas Brawijaya.

A Dale, Timpe. (1993). Kinerja. Jakarta: PT. Gramedia.

A.Suhaenah Suparno. (2001). Membangun Kompetensi Belajar. Direktorat Jendral Pendidikan Tinggi Departemen Pendidikan Nasional.

Avolio, B.J., B.M. Bass, D.I. Jung. (1999). Re-Examining the Components of Transformational andTransactional Leadership Using the Multifactor Leadership Questionnaire. Journal of Occupational and Organizational Psychology, 72, 441-462.

Bass, M. Bernard dan Reggio, E. Ronald. (2006). Transformational Leadership. Second Edition. New Jersey: Lawrence Erlbraum Associates, Inc.

Bass, B.M dan Avolio B.J (1990). Manual for The Multifactor Leadership Questionnaire. Alo Alto, CA: Consulting Psychology Press.

Bernardin, H. John and Russel. (2010). Human Resource Management. New York: McGraw-Hill

Bird, B. (2019). Chapter 6 Toward a Theory of Entrepreneurial Competency. Seminal Ideas for the Next TwentyFive Years of Advances, 115-131. 
Boahin, P., \& Hofman, W. H. A. (2014). Perceived effects of competency-based training on the acquisition of professional skills. International Journal of Educational Development, 36, 81-89.

Birasnav, M. (2014). Knowledge management and organizational performance in the service industry: The role of transformational leadership beyond the effects of transactional leadership. Journal of Business Research, 67(8), 1622-1629.

Bonder, A., Bouchard, C.-D., \& Bellemare, G. (2011). Competency-Based Management-An Integrated Approach to Human Resource Management in the Canadian Public Sector. Public Personnel Management, 40(1), 1-10.

Boulter, Nick. Murray Dalziel dan Jack Hill. (2003). The Art of HRD People And Competencies. Jakarta. Penerbit : PT. Buana Ilmu Populer.

Braun, S., Peus, C., Weisweiler, S., \& Frey, D. (2013). Transformational leadership, job satisfaction, and team performance: A multilevel mediation model of trust. The Leadership Quarterly, 24(1), 270-283.

Burns, J.M. (1978). Leadership. Harper \& Row. New York, NY

Cardy, R. L., \& Selvarajan, T. T. (2006). Competencies: Alternative frameworks for competitive advantage. Business Horizons, 49(3), 235245.doi:10.1016/j.bushor.2005.09.004

Campbell, C., Silver, I., Sherbino, J., Cate, O. T., \& Holmboe, E. S. (2010). Competency-based continuing professional development. Medical Teacher, 32(8), 657-662

Campion, M. A, Fink, A. A, Ruggeberg, B. J., Carl, L., Phillips, G. M., \& Odman, R. B. (2011). Doing Competencies Well: Best Practice in Competency Modeling. Personnel Psychology, 64(1), 225-262

De Vos, A., De Hauw, S., \& Van der Heijden, B. I. J. M. (2011). Competency development and career success: The mediating role of employability. Journal of Vocational Behavior, 79(2), 438-447.

Dionne, S. D., Yammarino, F. J., Atwater, L. E., \& Spangler, W. D. (2004). Transformational leadership and team performance. Journal of Organizational Change Management, 17(2), 177-193.

Eicker, S., Kochbeck, J., \& Schuler, P. M. (2008). Employee Competencies for Business Process Management. Lecture Notes in Business Information Processing, 251262. doi:10.1007/978-3-540-79396-0_22

Eric Soderquist, K., Papalexandris, A., Ioannou, G., \& Prastacos, G. (2010). From task-based to competency-based. Personnel Review, 39(3), 325346.

Gangani, N., McLean, G. N., \& Braden, R. A. (2008). A Competency-Based Human Resource Development Strategy. Performance Improvement Quarterly, 19(1), 127-139.

Gang Wang, Oh, I.-S., Courtright, S. H., \& Colbert, A. E. (2011). Transformational Leadership and Performance Across Criteria and Levels: A Meta-Analytic Review of 25 Years of Research. Group \& Organization Management, 36(2), 223-270.

García-Morales, V. J., Jiménez-Barrionuevo, M. M., \& Gutiérrez-Gutiérrez, L. (2012). Transformational leadership influence on organizational performance through organizational learning and innovation. Journal of Business Research, 65(7), 1040-1050.

Ghasabeh, M. S., Soosay, C., \& Reaiche, C. (2015). The emerging role of transformational leadership. The Journal of Developing Areas, 49(6), 459-467.

Gomes, Faustino Cardoso. (2003). Manajemen Sumber Daya Manusia. Jakarta: Andi Offset.

Gordon. (1988). Pembelajaran Kompetensi. Jakarta : Rineka Cipta.

Ghozali, I., \& Latan, H. (2015). Konsep, Teknik, Aplikasi Menggunakan Smart PLS 3.0 Untuk Penelitian Empiris. Semarang: BP Undip.

Jeou-Shyan, H., Hsuan, H., Chih-Hsing, L., Lin, L., \& Chang-Yen, T (2011). Competency analysis of top managers in the Taiwanese hotel industry. International Journal of Hospitality Management, 30(4), 1044-1054.

Hakim, dkk. (2009). "Pengembangan Kewirausahaan dengan Penerapan Kepemimpinan Transformasional dan Pengaruhnya Terhadap Usaha Ekstra Karyawan pada Industri Manufaktur Surakarta”. Surakarta

Hani, Handoko T. (2010). Efektivitas Kerja, Yogyakarta.

Handoko, T. Hani. (2004). Manajemen Personalia dan Sumber Daya Manusia. BPFE. Yogyakarta

Hartiti, Tri. (2013). Peningkatan Softskill Perawat Melalui Kepemimpinan Transformasional Kepala Ruang Pada RS Swasta di Semarang. Jurnal Manajemen Keperawatan. Volume 1, No 2, November 2013; 115-123

Hasibuan, M. (2013). Manajemen Sumber Daya Manusia. Bumi Aksara: Jakarta. Harsiwi, Agung M. (2003). Hubungan Kepemimpinan Transformasional dan Karakteristik Personal Pemimpin. Artikel. Yogyakarta

Hersey, P. dan K. Blanchard. (2010). Manajemen Perilaku Organisasi (terjemahan oleh Agus Dharma),. Erlangga.

Kark, R., \& Shamir, B. (2013). The Dual Effect of Transformational Leadership: Priming Relational and Collective Selves and Further Effects on Followers. Monographs in Leadership and Management, 77-101.

Kendra, Cherry. (2013). What is Transformational Leadership? How Transformational Leadership Inspire About. http://psychology.about.com/od/leadership/a/transformational.htm

Mangkunegara, A.A., Anwar Prabu (2005). Manajemen Sumber Daya Manusia Perusahaan. Rosda Karya. Bandung.

Mangkunegara, A.P. (2007). Manajemen Sumber Daya Manusia. Bandung: PT. Remaja Rosdakarya 
Mangkuprawira, Sjafri. (2003). Manajemen Sumber Daya Manusia Strategik. Jakarta: Ghalia Indonesia.

Mathis \& Jackson. (2002). Manajemen Sumber Daya Manusia. Jakarta: Selemba Empat

McDaniel, K. R., Ngala, F., \& Leonard, K. M. (2015). Does competency matter? Competency as a factor in workplace bullying. Journal of Managerial Psychology, 30(5), 597-609.

Moch Soe'oed Hakam, dkk. (2015). Pengaruh Gaya Kepemimpinan Transformasional terhadap Kinerja Karyawan dengan Motivasi Sebagai Variabel Intervening (Studi Pada Karyawan Bank Jatim Cabang Malang). Jurnal Administrasi Bisnis. Vol. 3, No. 1.

Morris, M. H., Webb, J. W., Fu, J., \& Singhal, S. (2013). A Competency-Based Perspective on Entrepreneurship Education: Conceptual and Empirical Insights. Journal of Small Business Management, 51(3), 352-369.

Müller, R., \& Turner, R. (2010). Leadership competency profiles of successful project managers. International Journal of Project Management, 28(5), 437-448.

Nawawi, Hadari. (2005). Manajemen Sumber Daya Manusia Untuk Bisnis yang Kompetitif .Cetakan Keempat. Penerbit Gajah Mada University Press, Yogyakarta.

Rauch, C.F., \& Behling, O. (1984). Functionalism : Basis for Alternate Approach to The Study of Leadership. New York: Pergamon Press.

Robbins, Stephen P. \& Judge, Timothy A. (2007). Perilaku Organisasi, buku 2. Jakarta: Salemba Empat.

Schien. (1992). Organizational Culture and Leadership. Jossey-Bass. SanFransisco. Sedarmayanti, (2011). Sumber Daya Manusia. Bandung, Mandar Maju.

Sekaran, Uma. (2003). Research Method for Business, A Skill Building Approach; Fourth Edition. USA John Wiley and Sons Inc.

Sikula, Andrew F. (1976). Personnel Administration and Human Resources Management. New York: John Wiley \& Sons

Simamora, Henry. (2006). Manajemen Sumberdaya Manusia. Yogyakarta: Sekolah Tinggi Ilmu Ekonomi YKPN. Situngkir, Sihol dan Amin, Sofia. (2006). Manajemen Sumberdaya Manusia. Jambi: UNJA PRESS.

Spencer, Lyle \& Signe M. Spencer. (1993). Competence at Work, Models For Superior Performance. Canada : John Wiley \& Sons, Inc.

Sugiono. (2016). Metode Penelitian Manajemen. Bandung: Alfabeta. Sunarto. (2003). Perilaku Organisasi. Yogyakarta: AMUS.

Sekaran, Uma dan Roger Bougie, (2017). Metode Penelitian untuk Bisnis: Pendekatan Pengembangan-Keahlian. Jakarta: Salemba Empat

Wexley, K.N., \& Yukl, G. (1977). Organizational Behavior and Personnel Psychology.

Richard D. Irwin: Home wood, Illinois.

Yukl, G. (2009). Kepemimpinan dalam Organisasi. Jakarta: PT. Indeks. 